\title{
Diseño Institucional y Des-colectivización en Chile: del Estado Social al Estado Neoliberal
}

\author{
Institutional Design and De Collectivization in Chile: \\ From the Social State to the Neoliberal State
}

\author{
Francisco Báez Urbina*
}

\begin{abstract}
Resumen: El presente artículo ofrece una visión del cambio constitucional chileno hecho a partir del idea de la des colectivización del diseño institucional operado en Chile desde la década 80. En ese contexto, ofrece un análisis comparativo de los textos constitucionales de 1925 y de 1980. La hipótesis central del texto señala que el actual modelo chileno se inscribe a un proceso mayor de "des-democratización" liberal global que viene blindado constitucionalmente.
\end{abstract}

Palabras clave: Diseño institucional, derechos sociales, neoliberalismo, Chile

\begin{abstract}
The present article offers a vision of the Chilean constitutional change made from the idea of the collectivization of the institutional design operated in Chile since the 1980s. In this context, it offers a comparative analysis of the constitutional texts of 1925 and 1980. The central hypothesis point of the text points, out that the current Chilean model is part of a larger process of global "de-democratization" that is constitutionally armored.
\end{abstract}

Keywords: Institutional design, social rights, neoliberalism, Chile

Recibido: 28 octubre 2016

Aceptado: 12 febrero 2017

\footnotetext{
* Chileno. Doctor en Sociología por la Universidad Autónoma de Barcelona. Docente e investigador de la Universidad de Playa Ancha y de la Universidad de Santiago de Chile. Artículo producto del Proyecto FONDECYT de Iniciación a la Investigación Año 2013, No 11130026, denominado: “Acción colectiva y diseño institucional. Una contribución desde la sociología analítica al estudio de los fundamentos y de las consecuencias de la des-colectivización en Chile”. Correo electrónico: francisco.baez@upla.cl
} 


\section{Presentación}

En el contexto actual de debate sobre el cambio de constitución, debate de coyuntura política nacional centrado en la disputa pública entre quienes desean un mejoramiento dentro del modelo socioeconómico (que agrupa a quienes plantean un ejercicio de cambio constituyente moderado o nulo) ${ }^{1}$ y quienes desean cambiar el patrón de acumulación (que agrupa a quienes quieren cambiar el texto constitucional completo); ${ }^{2}$ y del debate teórico normativo internacional de mayor amplitud y profundidad entre: i) el liberalismo económico estricto -actualmente hegemónico-, ${ }^{3}$ y ii) un republicanismo democrático de base socialista / social demócrata -que le disputa espacios de poder-, ${ }^{4}$ quisiéramos plantear un texto que recoja y refleje la centralidad que la idea del diseño institucional y constitucional debe tener en el análisis de cualquier proceso político, que sitúe el texto de la Constitución Política de la República (CPR) del 80 en su contexto institucional histórico internacional, y -en ese sentido- que lo describa como parte del ordenamiento des democratizador propio de la implantación del liberalismo contemporáneo global. ${ }^{5}$

En esa dirección, y en sintonía con las segundas posiciones planteadas en los dos debates recién señalados, creemos que las más de doscientas reformas hechas a la CPR desde 1989 en adelante, ${ }^{6}$ no han sido impedimento para que los preceptos doctrinarios de dicho texto (su módulo dogmático) se mantengan aún vigentes al día de hoy y continúen siendo hasta la fecha la esencia de lo que suele llamarse el "modelo chileno": un esquema institucional anti democrático, des democratizador, in-capacitador, neutralizador y desactivador, tanto del sano ejercicio de la política democrática de base republicana, como de la soberanía popular y sus capacidades de control democrático sobe el proceso de toma de decisiones públicas (Gárate, 2014; de Francisco, 2007). Sabemos que la visión de mundo que materializa dicho texto, ha exaltado, por ejemplo, ideales como la libertad negativa, ${ }^{7}$ representándola en torno a un conjunto de ideas y valores afines, como la propiedad privada, los derechos individuales, la libertad de enseñanza, la libertad de asociación y de empresa (Cristi, 2008). Todos ellos, ideales que, punto por punto, fundamentaron -en su momento- la oposición a la profundización del diseño institucional chileno nacional

\footnotetext{
${ }^{1}$ Centro político y derecha política (núcleos de estudio liberales de derechas - recepción local de programa Friedman / Harberger / Hayek- y neoconservadores -Nozick-).

${ }^{2}$ Izquierda académica y política (Fernando Atria, Carlos Ruiz, Alberto Mayol, entre otros).

${ }^{3}$ Que confronta a la teoría neoclásica o monetarista en ciencias económicas y sus derivados de diseño político, por un lado, y el keynesianismo socialdemócrata más una amplia gama de posiciones académicas y políticas centradas en el retorno de los derechos sociales y económicos y en la crítica a la globalización neoliberal, por otro.

${ }^{4}$ Repuesto, actualizado y amplificado por la crisis económica mundial del 2008 y sus consecuencias. Elementos de análisis como individualismo, privatización de derechos económicos y sociales, precarización, inseguridad, flexibilidad laboral, dan cuenta de dicho debate. Todos ellos, ponen de relieve -ya después de cuarenta años de neoliberalismo global- la tensión entre libertades individuales y derechos colectivos.

${ }^{5}$ Ver textos de Cristi (2000) y de Cristi y Ruiz Tagle (2014), por ejemplo.

${ }^{6}$ Y sobre todo en el 2005, año en el que se le hicieron 54 modificaciones.

${ }^{7}$ Cfr. Isaiah Berlin.
} 
desarrollista. ${ }^{8}$ En ese sentido, y combatiendo la noción de Estado social consagrado en Chile por la CPR de 1925, el paradigma implantado unilateralmente por las elites en Chile a mediados de los setenta, promovió un modelo de economía y sociedad particular, un proyecto de clase que -según Harvey (2007)- subordina la política a la economía y que remplaza la idea de los derechos colectivos por el de las libertades individuales. En relación a ello, la discusión sociológica, histórica, jurídica y politológica sobre la naturaleza y las consecuencias de la implantación y ejecución de la CPR de 1980, acumula cada vez mayor vigencia. $^{9}$

El presente artículo se construye con base en la hipótesis que señala que el actual modelo chileno se inscribe a un proceso mayor de des democratización liberal global, el cual se encuentra blindado constitucionalmente. Intenta abordar, a través del estudio de su dimensión constitucional, algunas de las características del diseño institucional chileno de las últimas cuatro décadas. Se establecen para ello algunos de los elementos básicos de una sociología del derecho a partir de lo que acá se entenderá por diseño institucional. De esta manera, se intentará establecer la relación entre el meta diseño institucional y diseño constitucional tomando como ejemplo la actual CPR (su relevancia y apuesta de innovación teórica). Esto, bajo el entendido que el meta diseño institucional sería un conjunto determinado de meta reglas del juego (reglas constitucionales, jurídicas, económicas, políticas y también psicológicas), que permiten y promueven cierto tipo de orientaciones en los intercambios entre particulares. En ese sentido, sostenemos que el meta diseño institucional contiene la cosa constitucional (constitución formal), la cosa organizacional estatal (la orientación, la forma y la cantidad de burocracia estatal) y la cosa institucional propiamente tal según el enfoque sociológico analítico (la estructura de incentivos, es decir, la psicología política resultante). Junto con ello, dicho meta diseño representa la correlación de fuerzas económicas, políticas y culturales existentes en una comunidad determinada (la constitución material). En ese sentido, como parte de la cosa meta institucional, el diseño constitucional es parte los fundamentos de la acción social; esto es, afecta tanto a las reglas objetivas de intercambio entre los jugadores (la constitucion formal) como a las creencias de estos (la psicología política resultante), o a los resultados del juego (la estructura económica y de propiedad, por ejemplo). Así, nuestra perspectiva indica que los diseños institucionales definidos centralmente (como nuestro caso de estudio) intervienen en el modo en el que los agentes se desenvuelven entre los sistemas de intercambio, privados y públicos, promoviendo cierto tipo de comportamientos y no otros. Evidentemente, las reglas del juego se modifican y reconfiguran, según las correlaciones de fuerza entre las clases sociales y sus proyectos (rediseños) de sociedad, y por lo tanto dependen, de un marco histórico y sociopolítico.

\footnotetext{
${ }^{8}$ Universalista, colectivista. Modelo que se extendiera durante gran parte del siglo XX.

${ }^{9}$ Podemos definir gatopardismo como el proceso de transformismo político institucional ejercido para mantener el statu quo: Que todo cambie para que todo siga igual. Ver Tomás Moulián, Chile Actual, Anatomía de un mito, Lom, 1997, o también Fernando Atria, La constitución tramposa, Santiago de Chile, Lom, 2013.
} 
Para efectos de este análisis, se propone una revisión histórica respecto de la transformación de los fundamentos y mecanismos meta-institucionales ${ }^{10}$ que, a nuestro juicio, habrían restringido la cultura de los derechos económicos y sociales colectivos, y promovido las libertades individuales (su relevancia y apuesta de innovación metodológica). De esta manera, creemos que los diversos procesos de des-colectivización y des-universalización puestos en operación en Chile desde el Estado, desde mediados de la década del setenta a la fecha, habrían incidido profundamente en la manera en cómo nos relacionamos como agentes con el Estado y con "los demás" en la esfera pública, económica y social. Se ahondará, entonces, en algunos de los elementos axiales de la dimensión constitucional del diseño neoliberal chileno, exponiendo algunos de los presupuestos ideológicos que estarían detrás de las consecuencias previstas, derivadas y observadas actualmente en la configuración estatal chilena actual: la des-democratización, la construcción de un orden institucional centrado en la libertad negativa ajeno a las contingencias del mercado electoral y a la representación y la competencia política partidista, y la concentración y desigual distribución de poder económico y político que tanto caracteriza a la sociedad chilena contemporánea.

\section{El diseño institucional y la economía política}

Hasta ahora hemos mencionado la noción de diseño institucional para referirnos a unas reglas de juego que rigen en abstracto a una comunidad política, pero, ¿qué es el diseño institucional desde la perspectiva racionalista en términos más concretos? Desde cierta versión de la sociología analítica (que conjunta republicanismo democrático con elección racional), entendemos como diseño institucional al conjunto de las "intervenciones en todos los acuerdos que coordinan la conducta de los individuos dentro de la sociedad" (...) "Incluyen los procedimientos establecidos a nivel constitucional o legalmente, pero también abarcan cuestiones que están apenas sujetas a normas y convenciones o que están fijadas únicamente por presiones y perspectivas tácitas o registradas acaso ocasionalmente" (Pettit, 2003: 76). Esta conceptualización está basada en al menos tres supuestos comportamentales básicos: i) la conducta en sociedad es sensible a oportunidades y a incentivos disponibles en ciertas situaciones de intercambio entre agentes; ii) dichas estructuras de oportunidades pueden ser modificadas externamente, de manera tal que se pueden obtener resultados agregados determinados esperados o no; y iii) existen ciertos criterios que pueden servir para evaluar si ciertos patrones agregados de conducta son más deseables que otros, dado lo cual puede resultar más atractivo promoverlos frente a otras alternativas o líneas de acción. De este modo, puede afirmarse que la conducta ha de perfeccionarse desde ciertos criterios producidos al interior del juego social y la disputa política. Las instituciones, o los resultados persistentes, son producto de la correlación de fuerzas propia de un escenario político determinado, y expresan hegemonías económicas,

10 Transformación que bien puede ser ilustrada mediante la idea modélica de "generaciones de Constituciones" que recogemos libre y genéricamente de los textos de Pisarello, 2011 (ver texto y bibliografía). 
políticas y culturales específicas. Por su parte, si el diseño consiste básicamente en la creación de un esquema o forma determinada de promover en una comunidad ciertos resultados valiosos y no otros, entendemos como rediseño institucional al conjunto de procesos de reorganización de la estructura de incentivos que re-encamine la obtención de ciertos resultados y no de otros. A veces incluye el recambio de los grupos que ejercen la hegemonía sociocultural, política y económica en un contexto o escenario de intercambio específico (Peters, 2003; Pettit, 2003). En nuestro caso puntual, dicho proceso de rediseño, que ha consistido fundamentalmente en un heterogéneo y general proceso de descolectivización intencionalmente promovido desde el Estado, el cual ha involucrado el desmantelamiento del capitalismo organizado o contra reformado propio del modelo nacional desarrollista keynesiano. ${ }^{11}$ Es decir, el derrumbamiento de la orientación universalista de los bienes públicos (BP) producidos por el Estado, la caída de la identidad colectiva referida a lo nacional, y el desprestigio observado de la actividad colectiva, como forma relevante de acción social, entre otros fenómenos asociados. Sostenemos que dicho proceso de rediseño se ha desarrollado por medio de diferentes mecanismos institucionales relacionados: la des-colectivización constitucional (la estructura de las reglas del juego a escala nacional), la des-colectivización organizacional pública (orientación y estructura de la administración estatal), y lo que desde la sociología analítica se define como 'lo institucional' propiamente tal y, que (para fines metodológicos), asociamos a lo cultural y la psicología política que hay detrás: el fomento de incentivos utilitaristas de primer orden a la no cooperación en la provisión de BP.

Consideramos el problema de la des-colectivización como el quiebre unilateral del contrato social entre clases por parte de la elite económica con respecto al resto del colectivo. Como venimos afirmando, ello se posibilitó sólo sobre la base de la caída inducida de la actividad colectiva como forma relevante de acción social, y del vaciamiento y la despolitización de la esfera social y económica; situaciones que generaron, la ya referida desigualdad en los resultados socioeconómicos obtenidos por los diferentes grupos sociales de la población. Entenderemos dicho quiebre unilateral, como un problema de acción colectiva entre clases o sectores sociales determinados, donde los resultados de la comunidad económica nacional, son considerados BP (Schelling, 1989; Elster, 1989, 2010; Báez Urbina, 2009). En este caso, un quiebre unilateral de la elite económica con respecto del resto de la población, o a decir por el ejercicio conceptual hecho por Elster y que nos aporta la base teórica central para nuestra reflexión, del capital respecto al trabajo (Cfr. 1989: 248). El rompimiento unilateral del contrato (golpe de Estado de 1973 y neo liberalización de la sociedad chilena post 1980), implicaba la desarticulación del compromiso de clases de la post guerra y las certezas y logros conseguidos por el movimiento social obrero, lo que condujo a la privatización y pérdida de patrimonio colectivo (propiedad pública), la desarticulación violenta de la acción colectiva popular de clase (destrucción de la organización social y obrera), y la revolución cultural neoconservadora a nivel de psicología política orientada a promover dicha inacción colectiva de clase (legitimación simbólica). En relación a ello, definimos la des-

\footnotetext{
${ }^{11}$ Imperativo liberal contra el Estado social: una matriz Estado-céntrica es esencialmente poco productiva, ineficiente, y eminentemente inflacionaria.
} 
colectivización como el proceso de desinstalación de las regulaciones colectivas y universalistas propias de la modernidad organizada del segundo y tercer cuarto del Siglo XX (el capitalismo organizado o reformado) que aseguraron ciertas protecciones y mecanismos de retribución de los resultados sociales y económicos logrados en términos macro: ${ }^{12}$ los derechos económicos y sociales (Castel, 2010 y et al 2013; Domènech y Raventós, 2010; Domènech, 2013 y 2013b; Harvey, 2007; Rosen, 2010). Así, la descolectivización estaría fuertemente asociada los procesos de privatización de la estructura institucional. En ese sentido, nos servimos del concepto de acumulación por desposesión propuesto y desarrollado por Harvey (2003, 2007). Estos procesos de privatización, desnacionalización, mercantilización de la sociedad y de financiarización de la economía, desde mediados de los años 70, funcionarían como línea de continuidad con procesos similares descritos por Marx en la naciente economía industrial capitalista, bajo su categoría de acumulación primitiva u originaria. En palabras del propio Harvey (2003), la des-colectivización puede entenderse como el conjunto:

(...) amplio de procesos, que incluyen la mercantilización y privatización de la tierra y la expulsión por la fuerza de las poblaciones campesinas; la conversión de varios tipos de derechos de propiedad (comunal, colectiva, estatal, etc.) en derecho de propiedad privada exclusivos; la supresión del acceso a bienes comunales; la mercantilización de la fuerza de trabajo y la supresión de formas alternativas (indígenas) de producción y consumo; los procesos coloniales, neocoloniales e imperiales de apropiación de bienes (incluidos los recursos naturales); la monitorización del intercambio y los impuestos, en particular sobre la tierra; la trata de esclavos; y la usura, la deuda nacional y más recientemente el sistema de crédito. El Estado, con su monopolio de violencia y su definición de la legalidad, desempeña un papel decisivo en el respaldo y promoción de estos procesos (Harvey, 2003: 116).

En efecto, la acumulación por desposesión es el amplio, complejo y profundo conjunto de procesos de privatización, de desmantelamiento de derechos universales, desnacionalización, precarización y trasferencia de riqueza bottom up (de abajo hacia arriba), vividos por la población de clase media y baja entre mediados de la década del setenta, a beneficio de la elite financiera, y que continua hasta el día de hoy. De esta manera, y para efectos de este escrito, suscribimos la hipótesis de Harvey $(2003,2007)$ que señala que todas las características propias de la acumulación originaria señalada por Marx siguen poderosamente presentes en los procesos de desinstalación de las regulaciones institucionales universalistas, desarrollistas y nacional populares (Domènech, 2013).

Creemos que el contrato, mecanismo analítico de resolución del problema de la acción colectiva, ilustra de manera apropiada el modelo de cooperación forzada. El contrato, el pacto de clases entre capital y trabajo conseguido con luchas sociales a nivel mundial y que funcionaba como restricción institucional regulatoria frenaba la acumulación de capital. La acción colectiva de carácter político y de clase que venía presionando al Estado inspirando las últimas modificaciones a la carta de 1925, frenaban el proceso de

\footnotetext{
${ }^{12} \mathrm{Y}$ que involucran importantes conquistas del movimiento obrero propio del siglo XX.
} 
acumulación de capital y atentaban ya claramente contra la estructura de propiedad. Y eso a fines de los sesentas, representaba el miedo a la destrucción de la economía capitalista periférica chilena. Había que destrabar la restricción. Desde el punto de vista del capital, había que dejar de contribuir con el modelo nacional desarrollista y construir un nuevo sistema de reglas del juego rompiendo el pacto. En el lenguaje analítico propio de la teoría de juegos, para el capital había que pasar corporativamente del estado de cooperación condicional bilateral (coopero con el otro, sólo si este, el factor trabajo, también lo hace), al de la no cooperación unilateral (dejo de hacerlo pues veo que el otro rompió el pacto incrementando sus presiones sobre el Estado, capturándolo, y rompiendo la estructura de propiedad: expropiaciones, nacionalizaciones, fortalecimiento de la propiedad social, etc.). La rebelión de las elites.

En lo que sigue, abordaremos la involución de los derechos económicos y sociales a partir de un pequeño examen referido a las generaciones de constituciones. Ello en la perspectiva de tipificar a la Constitución chilena de 1980 como el conjunto de reglas del juego que fundamentan el diseño constitucional propio del proceso de des-colectivización y des democratizador que se impuso en el país, entre mediados de la década setenta del Siglo XX y los primeros tres lustros del XXI. Sobre esto, una disquisición metodológica. Creemos que el diseño institucional (y constitucional) chileno guarda una correspondencia ajustada con el diseño institucional de las economías centrales. En ese sentido, con independencia de las particularidades de los mercados políticos nacionales, la CPR del 80, como la del 25, contienen elementos que se ajustan a los modelos de intercambio establecidos para el conjunto de las naciones del concierto mundial. De ahí la idea de generaciones de constituciones.

\section{La idea de las generaciones de constituciones y la involución de los derechos económicos y sociales}

Los derechos democráticos son el resultado de encarnizadas luchas sociales anti hegemónicas contra la concentración oligárquica y pueden ser ordenadas en oleadas, en etapas, en generaciones. En este sentido, es posible contar una historia de los flujos democratizadores, como también por desgracia, de los reflujos des democratizadores. Desde la antigua Grecia que el concepto de democracia viene, con altos y bajos, diluyéndose o perdiendo peso dentro del lenguaje y la práctica política romana o medieval, cediendo peso social frente a consideraciones oligárquicas o despóticas. Así, el sentido abstracto de democracia como el diseño propio del gobierno de los pobres libres, tras altos y bajos, fue cediendo peso y protagonismo frente a nociones como la de República o a la de Constitución mixta, situación que no impidió que en los últimos tres siglos surgieran y persistieran constantes luchas sociales, políticas y económicas anti oligárquicas que bien pueden ser consideradas como la prolongación histórico material del viejo ideal democratizador: la democracia económica y el control ciudadano a las élites. La democracia o las luchas por la democratización de las relaciones sociales en el contexto moderno, vienen expresando -desde hace siglos- una serie de tensiones históricas antagónicas que nos hablan de cómo se gobierna y para quienes se gobierna. Así, el diseño 
de las reglas del juego para los sistemas de intercambio se constituyen de manera estructural, entre la disputa típica entre igualdad y desigualdad, entre concentración o distribución del poder o, entre el gobierno de todos o de la mayoría, y las diferentes conjugaciones de los diseños oligárquicos, elitistas o autoritarios (Pisarello, 2011). (Cfr. (Piketty, 2014, quien nos señala que la desigualdad es producto de que la tasa de acumulación de la renta o de retorno de los beneficios del capital siempre es mayor que el crecimiento económico: $r>g$ ).

\subsection{Las constituciones sociales republicanas del período de entreguerras}

Las constituciones republicanas de entreguerras expandieron el concepto de democracia y de los derechos humanos universales provenientes del iusnaturalismo revolucionario medieval tardío (Pisarello, 2011). Se inspiraron en la Constitución inglesa de 1648, en la norteamericana de 1776, y en la de la Primera República Francesa, sobre todo en su proceso jacobino (a partir de 1792 y hasta 1795). Eran diseños construidos a partir de las posibilidades constituyentes del cuarto Estado, y de categorías históricopolíticas sustantivas como la economía moral de la multitud de E. P. Thompson, o de la economía política popular de Robespierre. Cuando la Primera Guerra Mundial puso en crisis al capitalismo financiarizado, liberal, imperialista y belicista de la Belle Epoque, desató además una fuerte ola de revueltas sociales, populares y obreras que fueron canalizadas institucionalmente, o bien por la vía reformista, como en algunos países de europeos continentales, o bien por vía revolucionaria, como algunos países en donde la estructura de propiedad estaba demasiado concentrada o donde la represión estatal venía siendo demasiado excesiva. La revolución mexicana iniciada en 1910, la revolución rusa e incluso la revolución china de 1911 datan de aquel período. Dentro de ellas, y en América Latina, la revolución mexicana, se identificó como una línea de continuidad de la tradición republicana - democrática de la Revolución Francesa de 1789. Ejemplo de ello es su artículo número 5, 'sobre la necesaria intervención reequilibradora del aparato estatal en las relaciones laborales', pero también el famoso y paradigmático 27 'sobre la limitación a la propiedad privada por interés público o social previendo la expropiación, que consideraba la reforma agraria e incluía la anulación de actos que implicasen el acaparamiento de bienes como tierras, aguas y riquezas naturales'. El artículo 123, que complementaba el número 5, limitaba la jornada laboral y los trabajos extraordinarios, dictando previsiones en materia de descansos, salarios, participación de obreros en utilidades de las empresas privadas, indemnizaciones en casos de accidente laboral, protección de la mujer obrera y del menor obrero, jurisdicción laboral, reglas de despido, irrenunciabilidad de los derechos del trabajador, de la seguridad social, etc.). Si bien estos artículos no eran parte de un cuerpo institucional de impronta socialista, reconocían una amplia gama de derechos que armonizaban los derechos del trabajo con los del capital. De este período de auge global de demandas sociales y de luchas sociales por doquier, también podemos mencionar, por ejemplo, la primera Constitución soviética de Junio de 1918, que también se reconoce como heredera de la revolución francesa, la Constitución húngara de 1919 fundada en la soviética, la Constitución parlamentaria de Weimar en Alemania, la Constitución austríaca 
de 1920, y la Constitución de la Segunda República española. Un conjunto importante de movimientos políticos y sociales provenientes tanto de tradiciones republicanas, como socialistas, comunistas e incluso libertarias de corte anarquistas o anarco sindicalistas, propias de la organización obrera y popular de aquellas décadas se concibieron como las herederas del ideal democrático estándar, concebido como un movimiento progresista universal que aspiraba 'al autogobierno fraterno de los productores libres' (Pisarello, 2011). Muchas experiencias de conformación de diseños institucionales democráticos intentaron consolidarse, y muchos fueron vistos como expresiones elevadas de una concepción de la democracia que pretendía ser política pero también social (como la Comuna de París de 1871, por ejemplo). Todas estas experiencias reflejaron el intento de los sectores populares (clases trabajadoras y ciertos sectores medios), de imponer por distintas vías regímenes políticos orientados a democratizar la vida política y económica, y de poner en crisis al capitalismo rentista y especulativo de comienzos de siglo. No obstante ello, este impulso democratizador radical terminará eclipsado por fenómenos anti democráticos y totalitarios como el nazismo, el fascismo y el estalinismo. De esta manera, todo este constitucionalismo social, todas estas experiencias de desarrollo institucional social, popular y jacobino centradas en la construcción de un Estado social de derecho se ven eclipsadas. Todo este constitucionalismo revolucionario que se había constituido en la posibilidad de actualización, proyección y consolidación del viejo proyecto republicano democrático fracasa en lo sustantivo, cerrando -de esta manera y en el contexto de un tipo de capitalismo financiero y belicista- un potente ciclo de apertura y democratización de las relaciones sociales dentro y fuera de la empresa.

\subsection{Las constituciones sociales del período de postguerra}

A diferencia del anterior, el constitucionalismo social de postguerra se construiría sobre pretensiones políticas más integradoras socialmente hablando, que revolucionarias o emancipatorias. Su objetivo fue el de regular el capitalismo liberal pero sin superar la lógica de acumulación perversa que depriva a los intereses de las grandes mayorías. Esto es, intentó garantizar un cierto nivel de seguridad social a cambio de desactivar la condición política de la ciudadanía, provocando, como efecto esperado (o ¿no esperado?), un déficit en las expectativas democráticas de los sectores medios y bajos. Así, se configuraba el contrato social de posguerra: el capital aceptaba distribuir socialmente parte de los excedentes de la producción mediante políticas fiscales distributivas basadas en el reconocimiento de cierto grado de derechos económicos y sociales, comprometiéndose a la vez a aceptar prácticas sindicales interesantes pero despolitizadas. A cambio de ello, el sector trabajo organizado renunciaba a la superación de la lógica de acumulación capitalista, lo que suponía moderar el conflicto social y el respeto de la estructura de propiedad privada. En ello consistía el contrato social entre capital y trabajo de post guerra. Una Constitución social mixta pero políticamente moderada, en donde el principio democrático, reconvertido en mecanismo de recambio de élites, no consiguiera una posición dominante respecto del componente oligárquico. 
De esta manera, y en la dirección de plantear un par de cosas de carácter contextual, antes de entrar en el análisis sociológico de la constitución chilena de 1980 y la de 1925 que le antecede, es conveniente decir que el consenso del bienestar de los años 50 y 60 bien puede entenderse, a partir de una serie de antecedentes institucionales. En 1944, por ejemplo, se dictó en Filadelfia, EEUU, la primera Declaración internacional de derechos con vocación de universalidad. Se firman los acuerdos de Bretton Woods (cuyo objetivo era el de la des mundialización del capitalismo especulativo que había llevado al mundo a la Gran Guerra), se crea las Naciones Unidas, y en 1948 se firma la carta fundamental de la Declaración Universal de los Derechos Humanos (cuya principal intención era la de bloquear la reaparición del nazismo y del fascismo a nivel mundial y recuperar tras 150 años, el sentido de los derechos humanos universales y genéricos). Ahora bien, las grandes guerras y la contienda social, política y económica de comienzos del Siglo XX generaron condiciones para un nuevo pacto social también en América Latina. En ese contexto, en nuestro país, pese a que el método de la asamblea constituyente de asalariados e intelectuales no prospera, desde una comisión ejecutiva observada por los militares se aprueba un texto más cercano a los contenidos propios del modelo de constitucionalismo social europeo de entreguerras que a los de postguerra: La Constitución chilena aprobada tras la reincorporación a la presidencia de Arturo Alessandri y vigente hasta el golpe de Estado de 1973. "Se trataba de un texto avanzado, no del todo sorprendente en un país que había conquistado el voto masculino universal y secreto en 1874 , con anterioridad a otros países como Bélgica, Dinamarca, Noruega o Francia, que en 1932 llegó a proclamar una efímera República socialista, y unos años más tarde, vio surgir un gobierno de Frente Popular presidido por el radical Pedro Aguirre Cerda" (Pisarello, 2011:155). La Constitución chilena de 1925 crea un Ejecutivo fuerte y le otorga al Estado un papel fundamental tanto en el desarrollo político, económico, social como cultural del país. Consagra un Estado Social de Derecho, que fue perfeccionándose durante su evolución política hasta 1973. En línea con los desarrollos constitucionales de comienzos de siglo, estableció la protección al trabajo, a la industria y a la previsión social, especialmente en lo referido a las condiciones básicas y materiales de reproducción de la vida de los integrantes de la comunidad política. Fue modificada en varias ocasiones (años 1943, 1957, 1959, 1963, 1967, 1969, 1970 y 1971), como parte de un proceso importante que debe enmarcarse dentro de las demandas del movimiento obrero y social frente al Estado, durante la segunda mitad del siglo XX. Uno de los últimos períodos políticos de dicho arreglo constitucional se correspondió con el proyecto de transición democrática al socialismo (la Vía Chilena al Socialismo) gestado en el país durante el gobierno de Salvador Allende Gossens. Allende, que había sido ministro del Frente Popular en los 30, apoyado por un conglomerado de centro - izquierda, defendía un particular programa que propugnaba una vía reformista e institucionalista al socialismo democrático.

Intentos reformistas importantes también en Latinoamérica los podemos encontrar en Uruguay (constituciones socialdemócratas de 1934, 1938 y 1942), en la reactivación y profundización de los contenidos propios de la constitución mexicano-jacobina de 1917, en elementos reformistas mezclados con populismo y nacionalismo en Argentina (Constitución de 1949), o en el nacionalismo corporativista brasileño (Constituciones de 
1934 y 1937). Pero la oligarquía no podía aguantar tanta concesión al trabajo y las clases medias y populares. El golpe de Estado cívico militar perpetrado el 11 de septiembre de 1973 marcará el fin de una época y se convertirá en un fuerte mensaje lanzado a las fuerzas sociales democratizadoras a nivel mundial. A partir de ahí, "la crítica igualitaria y democratizadora a los límites de las constituciones sociales (y socialistas) de posguerra, daría paso a un período de fuerte restauración liberal doctrinaria cuyo aleccionador Termidor había tenido en Chile un laboratorio privilegiado" (Pisarello, 2011:168). (Cfr. Gargarella, 2014; Domènech, 2013; Klein, 2010; Harvey, 2007).

\subsection{La constitución mixta global y el constitucionalismo antidemocrático}

En la Europa continental de la post guerra, y también en América Latina, si bien en los primeros años hubo varios intentos por diseñar sistemas constitucionales con cierto carácter social, a medida de que se fue avanzando hacia la década del ochenta, estos fueron perdiendo cada vez más intensivamente sus contenidos democráticos originales. Para el liberalismo doctrinario se había instalado política y académicamente la idea de que la intervención pública estatal ponía en riesgo la libertad individual y la salud de los mercados privados cada vez más en despliegue. Había pues que poner el orden espontáneo a resguardo del voto y la soberanía popular (la tiranía de la mayoría), todo lo cual suponía la recuperación de los supuestos básicos del liberalismo doctrinario clásico y de los intereses sustantivos previstos en el pensamiento elitista estándar. Se trataba, por tanto de limitar la posibilidad que el vulgo se inmiscuyera en las leyes autónomas de la economía abstracta y formalizada, poniendo a la idea del orden espontáneo por sobre la idea democrática de la justicia distributiva: Limitar la injerencia de los parlamentos y de la soberanía popular sobre la economía. A partir de los años ochenta, las transformaciones tecnológicas propias de la producción industrial y el tamaño cada vez menor de las empresas (Sennett, 2006) fueron debilitando a nivel mundial las condiciones para la organización sindical propias del fordismo o capitalismo organizado o reformado. El consenso de Washington, o la formalización académico política de la rebelión de las élites, llega -despreocupándose del pleno empleo- a consagrar una serie de medidas antiinflacionarias que exigían una contención de los derechos económicos y sociales conseguidos tras décadas de luchas sociales de carácter político y sindical. Estas vuelven a retomar el sitial perdido tras décadas de repliegue en la hegemonía política y cultural decidiendo acelerar la ruptura unilateral del contrato o consenso de post guerra. De hecho, dicha ruptura unilateral,

comenzó a cobrar mayor visibilidad a medida que fue desplegándose el concepto conocido como "globalización". Este neologismo detectaba cambios importantes en las relaciones internacionales, como la vertiginosa financiarización de la economía propiciada por la aparición de nuevos soportes tecnológicos y por la revolución informática. Sin embargo, estaba lejos de describir un fenómeno totalmente novedoso. Más bien comportaba una suerte de reviviscencia del capitalismo pre reformado, mundializado y belicista de la belle époque anterior a la Primera Guerra Mundial" (Pisarello, 2011: 180). 
De esta manera, estamos en presencia de una Constitución que avala y da legitimidad a una economía global única. Este derecho mercantil mundializado tendrá como objeto el generar una plataforma hegemónica nueva, una Constitución mixta (en ciertos casos supraestatal como lo es la europea), y muy diferente a la Constitución social que había regido los intercambios sociales durante casi todo el Siglo XX. En ella, podrán reconocerse sin problemas la posición dominante de los intereses corporizados del gran capital financiero global (y sus referentes locales en formato de nacionalismo metodológico), y los gerentes públicos y privados de las economías centrales o de algunas periféricas que disciplinadamente suscribieron el nuevo pacto. Frente a este marcado peso oligárquico, el elemento democrático permanecerá subordinado. Para el caso de los países de América Latina, estos mandatos tecnocráticos supranacionales van a acabar configurando una especie de Lex mercatoria a la que las constituciones nacionales o arreglos de diseño de todo tipo deberán someterse (Pisarello, 2011). Constituciones garantistas como la brasileña, fueron objeto de reformas o permanentes intentos de reforma para devaluar su alcance social. Otros casos son Colombia, el propio México y el PRI quien propugna el artículo 27 constitucional, el Perú de Fujimori, la Argentina de Menem consigue reformar la constitución en 1994, o la propia Constitución del 80 de Guzmán y Pinochet en Chile, entre otros. En definitiva, tenemos arreglos institucionales neoliberales, un esquema institucional basado en la recomposición radical de las relaciones de poder, en la restauración del poder de clase de las elites pero esta vez en su versión bancariofinanciera. De esta manera, se repone el peso fundamental de la gran propiedad y de las libertades individuales, reduciéndose el ejercicio de la soberanía popular a la mera comparecencia a elecciones poco competitivas, donde las alternativas de programas los ofrecidos no tienen mucha diferencia entre sí. O liberalismo de derechas o liberalismo de izquierdas, situación que ha supuesto un enorme y devastador golpe a los procesos de democratización política y económica logrados por los movimientos políticos y sociales del último siglo y medio a nivel mundial. Ahora bien, este nuevo constitucionalismo conlleva la des-democratización y la restauración de poderes conservadores que relegan a los componentes institucionales democráticos a niveles de subordinación vistos con anterioridad a la revolución constitucionalista social de comienzos del Siglo XX.

Hablamos entonces del paso de la esperanza democratizadora en un sentido distributivo, a la reacción social totalitaria del capital financiero bancario. Del paso de la seguridad material y la renuncia democrática a la Constitución mixta des-democrática. Como bien señala Bowles (2004) en términos de diseño institucional, el éxito y el fracaso son acumulativos.

\section{Elementos para una comparación de las Constituciones chilenas de 1925 y de 1980}

En lo que sigue, entregaremos algunos antecedentes que nos sirven para establecer las diferencias que creemos significativas del paso de la Constitución de 1925 a la del 80, es decir, el paso de la versión local nacional del constitucionalismo mundial de 
entreguerras, ${ }^{13}$ al constitucionalismo liberal, católico y autoritario, ${ }^{14}$ versión local nacional del constitucionalismo global mercantil.

\subsection{Algunos antecedentes sobre la Constitución de 1925: Los derechos sociales de la generación de post guerra}

La Constitución de 1925 promulgada por Arturo Alessandri Palma, pese a haber desautorizado la Asamblea de Obreros e Intelectuales del mismo año, y la que proponía una serie de contenidos sumamente adelantados desde el punto de vista de las reivindicaciones sociales y obreras frente a la oligarquía, ${ }^{15}$ consistía -como ya fuera señalado- en "un texto avanzado, no del todo sorprendente en un país que había conquistado el voto masculino universal y secreto en 1874, con anterioridad a países como Bélgica, Dinamarca, Noruega, o Francia, que en 1932 llegó a proclamar una efímera República Socialista, y que seis años más tarde vio surgir un gobierno de Frente Popular" (Pisarello, 2011:155). Impuso un régimen presidencialista, otorgó facultades al ejecutivo para nombrar y remover a ministros de Estado concediéndole a este facultades colegisladoras como, por ejemplo, presentar proyectos ante el Congreso, separó la Iglesia del Estado consagrando la libertad de culto, suprimió el Consejo de Estado y la Comisión Conservadora, creó el Tribunal calificador de elecciones, creó el recurso de inaplicabilidad constitucional, y en materia de garantías constitucionales, se incorporaron derechos sociales que -respecto de la institucionalidad liberal conservadora del Siglo XIX- significaron un gran avance en el ámbito de los derechos de la ciudadanía y del mundo del trabajo (sólo la Constitución mexicana de 1917 y de Weimar de 1919 habían consagrado dichos derechos; dentro de ellos, el concepto de "función social" de la propiedad, por ejemplo). ${ }^{16}$ Sus características son: Es una

\footnotetext{
${ }^{13}$ Tal vez, "la Constitución del 25 es la que más se acerca a una Constitución de un Estado social, no sólo por la presencia de un catálogo de derechos sociales (Art. 10), sino porque tratándose de ciertos derechos específicos, como el derecho de propiedad, a éste le corresponde una función social". En Christian Viera, Libre Iniciativa Económica y Estado Social: Análisis al estatuto de la libertad de empresa en la Constitución chilena, Santiago de Chile, Thomson Reuters, 2013:182.

${ }^{14}$ Posición que proviene del corporativismo católico propio de la encíclica Cuadragésimo Anno de 1931 y que Guzmán suscribe en sus primeros años de trayectoria intelectual y política.

${ }^{15}$ Según Sergio Grez, los principios que se acordaron como guías para la elaboración de la CPR de 1925 emanados de la Asamblea Constituyente de Obreros, e Intelectuales del mismo año, fueron: "la socialización de la tierra y de los medios de producción; la forma federal del gobierno; el deber del Estado de coordinar y fomentar la producción y asegurar la distribución de los productos; el sistema colegiado de gobierno tanto a nivel comunal, nacional como de los Estados federados; la organización del Poder Legislativo en base a "cámaras funcionales", compuestas por representantes (revocables en todo momento) de los gremios organizados; la separación de la Iglesia del Estado; la enseñanza gratuita desde la escuela hasta la Universidad, colocando su dirección en manos de los maestros, padres y estudiantes; la igualdad de derechos políticos y civiles de ambos sexos y la supresión del ejercito permanente". En Sergio Grez, "La ausencia de un poder constituyente democrático en la historia de Chile", en Revista izquierdas, Año 3, No 5, 2009:12.

${ }^{16}$ Pone al país en consonancia con la conformación de un proto Estado Social de Derecho, esto es, pone a la institucionalidad chilena en sintonía con las demandas emanadas de la "cuestión social" (en cierto sentido, se puede decir que sus contenidos se establecen en respuesta a ella), y con la cultura instalada a nivel mundial de los derechos sociales en cuestiones centrales como trabajo, industria, obras de previsión social y salud pública. También sintoniza con la idea de la tributación progresiva.
} 
constitución escrita y semirrígida o semiflexible, esto es, para su reforma requiere los trámites de una ley ordinaria pero con un quórum más alto; es una constitución sumaria y democrática; sumaria porque en su generalidad sólo indica las bases esenciales y deja a cargo del legislador su detalle, y es democrática porque fue aprobada mediante plebiscito pese a que en su gestación la mano militar tuvo un peso relativo; por último, es una constitución básicamente dogmática y orgánica (Verdugo, Pfeffer y Nogueira, 2005: 2327). Se aplica a cabalidad hasta $1973 .{ }^{17}$ Entre las reformas más importantes que se le hicieron hasta su derogación mediante Decreto Ley por la dictadura militar en 1981, se destacan: las reformas de los años 1943 (da rango constitucional a la Contraloría General de la República, da facultades exclusivas al presidente para alterar la división política administrativa del país, crear servicios públicos, empleos y sueldos de los mismos y dictar decretos de emergencia económica); las reformas del año 1957 (reformas con respecto a la nacionalidad), del año 1959 (reformas al sistema electoral), las reformas de los años 60 ("Ley de reforma agraria de macetero" de Frei Montalva; las del año 1967 que facilitan la expropiación, potencian el concepto de función social de la propiedad, definen el uso público de las aguas y se reforman los circunscripciones electorales); y las del año 1971, entre las cuales está - entre otras- la creación del Tribunal Constitucional (solicitado por los sectores conservadores del país como salvaguarda complementaria al Estatuto de Garantías Constitucionales de 1970 que la DC exige firmar a Allende para brindarle su apoyo electoral). Con todo, las reformas de la CPR del 1925 hechas durante el período, van modificando la carta magna original en el sentido de darle más atribuciones el ejecutivo, darle al país una organización político administrativo diferente, o para acentuar la función social de la propiedad (Verdugo, Pfeffer y Nogueira, 2005: 27-42). En todo caso, sea cual fueren las intenciones de los gobernantes del período desarrollista, lo cierto es que fueron reformas a la carta magna original cuyos principios básicos siempre estuvieron en sintonía con los fundamentos nacional democráticos propios del capitalismo organizado.

Respecto de los fundamentos en el Capítulo I, denominado Estado, Gobierno y Soberanía, la CPR 1925 señala que "El Estado de Chile es unitario. Su Gobierno es republicano y democrático representativo" (Artículo 1), y "La Soberanía reside esencialmente en la Nación, la cual delega su ejercicio en las autoridades que esta Constitución establece" (Artículo 2). Por otro lado, en el Capítulo III, reformado después del año 1971, señala:

La Constitución asegura a todos los ciudadanos el libre ejercicio de los derechos políticos, dentro del sistema democrático y republicano. Todos los chilenos pueden agruparse libremente en partidos políticos, a los que se reconoce la calidad de personas jurídicas de derecho público y cuyos objetivos son concurrir de manera democrática a determinar la política nacional. Los partidos políticos gozarán de libertad para darse la organización interna que estimen conveniente, para definir y modificar sus declaraciones de principios y programas y sus acuerdos sobre política

\footnotetext{
${ }^{17}$ Bajo su vigencia gobernaron Alessandri Palma (1932-1938), Aguirre Cerda (1938-1942), Juan Antonio Ríos (1942-1946), González Videla (1946-1952), Ibáñez del Campo (1952-1958), Alessandri Rodríguez (1958-1964), Allende Gossens (1970-1973), y Junta Militar (1973-1981).
} 
concreta, para presentar candidatos en las elecciones de regidores, diputados, senadores y Presidente de la República, para mantener secretarías de propaganda y medios de comunicación y, en general, para desarrollar sus actividades propias. La ley podrá fijar normas que tengan por exclusivo objeto reglamentar la intervención de los partidos políticos en la generación de los Poderes Públicos. Los partidos políticos tendrán libre acceso a los medios de difusión y comunicación social de propiedad estatal o controlados por el Estado, en las condiciones que la ley determine, sobre la base de garantizar una adecuada expresión a las distintas corrientes de opinión en proporción a los sufragios obtenidas por cada una en la última elección general de diputados y senadores o regidores (Artículo 9).

Ahora bien, y haciendo una selección respecto de los derechos provistos y señalados en su Artículo 10, "la Constitución asegura a todos los habitantes de la República:

$1^{\circ}$. La igualdad ante la ley. En Chile no hay clase privilegiada.

$4^{\circ}$. El derecho de reunirse sin permiso previo y sin armas. En las plazas, calles y demás lugares de uso público, las reuniones se regirán por las disposiciones generales que la ley establezca;

$5^{\circ}$. El derecho de asociarse sin permiso previo y en conformidad a la ley;

$7^{\circ}$. La libertad de enseñanza. Sólo la educación privada gratuita y que no persiga fines de lucro recibirá del Estado una contribución económica que garantice su financiamiento (...). La educación que se imparta a través del sistema nacional será democrática y pluralista y no tendrá orientación partidaria oficial. Su modificación se realizará también en forma democrática, previa libre discusión en los organismos competentes de composición pluralista.

$10^{\circ}$. El derecho de propiedad en sus diversas especies. La ley establecerá el modo de adquirir la propiedad, de usar, gozar y disponer de ella y las limitaciones y obligaciones que permitan asegurar su función social y hacerla accesible a todos. La función social de la propiedad comprende cuanto exijan los intereses generales del Estado, la utilidad y la salubridad pública, el mejor aprovechamiento de las fuentes y energías productivas en el servicio de la colectividad y la elevación de las condiciones de vida del común de los habitantes. Cuando el interés de la comunidad nacional lo exija, la ley podrá reservar al Estado el dominio exclusivo de recursos naturales, bienes de producción u otros, que declare de importancia preeminente para la vida económica, social o cultural del país. Propenderá, asimismo, a la conveniente distribución de la propiedad y a la constitución de la propiedad familiar. Nadie puede ser privado de su propiedad sino en virtud de la ley general o especial que autorice la expropiación por causa de utilidad pública o de interés social, calificada por el legislador. La ley podrá reservar al dominio nacional de uso público todas las aguas existentes en el territorio nacional y expropiar, para incorporarlas a dicho dominio, las que sean de propiedad particular. En este caso, los dueños de las aguas expropiadas continuarán usándolas en calidad de concesionarios de un derecho de aprovechamiento y sólo tendrán derecho a la indemnización cuando, por la extinción total o parcial de ese derecho, sean efectivamente privados del agua suficiente para satisfacer, mediante un uso racional y beneficioso, las mismas necesidades que satisfacían con anterioridad a la extinción.

$14^{\circ}$. La libertad de trabajo y su protección. Toda persona tiene derecho al trabajo, a 
la libre elección de éste, a una remuneración suficiente que asegure a ella y su familia un bienestar acorde con la dignidad humana y a una justa participación en los beneficios que de su actividad provengan. El derecho a sindicarse en el orden de sus actividades o en la respectiva industria o faena, y el derecho de huelga, todo ello en conformidad a la ley. Los sindicatos y las federaciones y confederaciones sindicales, gozarán de personalidad jurídica por el sólo hecho de registrar sus estatutos y actas constitutivas en la forma y condiciones que determine la ley. Los sindicatos son libres para cumplir sus propios fines. Ninguna clase de trabajo o industria puede ser prohibida, a menos que se oponga a las buenas costumbres, a la seguridad, o a la salud pública, o que lo exija el interés nacional y una ley lo declare así.

$16^{\circ}$. El derecho a la seguridad social. El Estado adoptará todas las medidas que tiendan a la satisfacción de los derechos sociales, económicos y culturales necesarios para el libre desenvolvimiento de la personalidad y dignidad humanas, para la protección integral de la colectividad y para propender a una equitativa redistribución de la renta nacional. La ley deberá cubrir, especialmente, los riesgos de pérdida, suspensión o disminución involuntaria de la capacidad del trabajo individual, muerte del jefe de familia o de cesantía involuntaria, así como el derecho a la atención médica, preventiva, curativa y de rehabilitación en caso de accidente, enfermedad o maternidad y el derecho a prestaciones familiares a los jefes de hogares. Es deber del Estado velar por la salud pública y el bienestar higiénico del país.

$17^{\circ}$. El derecho a participar activamente en la vida social, cultural, cívica, política y económica con el objeto de lograr el pleno desarrollo de la persona humana y su incorporación efectiva a la comunidad nacional. El Estado deberá remover los obstáculos que limiten, en el hecho, la libertad e igualdad de las personas y grupos, y garantizará y promoverá su acceso a todos los niveles de la educación y la cultura y a los servicios necesarios para conseguir esos objetivos, a través de los sistemas e instituciones que señale la ley. Las Juntas de Vecinos, Centros de Madres, Sindicatos, Cooperativas y demás organizaciones sociales mediante las cuales el pueblo participa en la solución de sus problemas y colabora en la gestión de los servicios del Estado y de las Municipalidades, serán personas jurídicas dotadas de independencia y libertad para el desempeño de las funciones que por la ley les correspondan y para generar democráticamente sus organismos directivos y representantes, a través del voto libre y secreto de todos sus miembros" (CPR 1925, Artículo 10).

Ya al final del período de su aplicación (a comienzos de los años 70), y sumando sus fundamentos originales más todas sus modificaciones posteriores de sensibilidad social manifiesta, la CPR de 1925 ya incluía o ya sintonizaba con las definiciones propias de un programa socialista democrático, programa de gobierno que fue diseñado y aplicado parcialmente por el gobierno de la Unidad Popular, conglomerado de partidos de izquierda y centro izquierda liderado por Salvador Allende, y que proclamaba la "vía chilena al socialismo". Dicho programa incluía "la estatización de áreas clave de la economía, la nacionalización del cobre, la aceleración de la reforma agraria, y la expansión simultánea de derechos políticos y sociales básicos. Muchas de estas actuaciones se llevaron a cabo a través de los resquicios legales que ofrecía el Decreto Ley № 520 que databa de la fugaz 
República Socialista de 1932 y que había caído en el olvido, a pesar de conservar valor legal" (Pisarello, 2011:167). El resto de la historia ya lo conocemos. En palabras de Pisarello, "al final el programa de la Unidad Popular, como otros programas republicanodemocráticos en la historia, se estrelló contra un muro en el Poder Judicial, en la Administración y en el Ejército, todas piezas claves de un Estado con el que las oligarquías internas y externas probarían tener estrechos vínculos" (Pisarello, 2011:168). Las acusaciones de Allende ante NU y en contra del poder de las grandes corporaciones globales que vienen amenazando el poder y la autoridad de los Estados sociales, marcarán el escenario que se avecina: El golpe de Estado de 1973 y la restauración liberal autoritaria entendidos como un quiebre unilateral del contrato construido sobre el consenso de post guerra. "Estamos frente a un verdadero conflicto frontal entre las corporaciones trasnacionales y los Estados. Estos aparecen interferidos en sus decisiones fundamentales, políticas, económicas y militares, por organizaciones globales que no dependen de ningún Estado, y que en la suma de sus actividades no responden ni están fiscalizadas por ningún parlamento o ninguna institución representativa del interés colectivo. En una sola palabra, es toda la estructura política del mundo la que está siendo socavada", señalará Allende en 1972 con extraordinaria y premonitoria claridad. No obstante ello, es interesante recalcar el hecho de que el factor explicativo principal de acuerdo a la visión republicano democrático actual es que la CPR del 1925 representaba los contenidos básicos del consenso republicano de entre guerras, y por tanto, ya era extemporánea respecto de las necesidades del capital de fines de los años 60. (La crisis de acumulación de capital de Harvey, 2007) En palabras de Domènech:

Chile y Argentina se configuraron políticamente en la era de la seguridad de un modo muy similar a los países europeos, con izquierdas políticas y movimientos sindicales homologables. Incluso después de la Gran Guerra, en los años veinte, Chile se dotó de una constitución republicana nueva, semejante en espíritu a las de la mayoría de los países europeo-continentales post monárquicos (...) Sin embargo, en la medida en que esos países quedaron intocados por la catástrofe europea de 194045 (...) no modificaron sus constituciones de anteguerra. Chile es un caso particularmente ejemplar: es en cierta medida el mantenimiento de su Constitución de 1925 lo que explica cosas como la particular vitalidad de su vida parlamentaria en los años 50 y 60, o el mantenimiento de una interesante y poderosa (...) ala izquierda en el partido socialista chileno (Altamirano), o, finalmente, la posibilidad de que se repitiera en Chile, como en la Europa de entreguerras, un experimento político de gobierno frente populista como el de la Unidad Popular de Salvador Allende en 1971. El golpe de Pinochet (...) abortó ese experimento (...) En lo que tal vez se insiste menos es en el hecho de que la vuelta de las libertades políticas en Chile no vino de la mano de una restauración de la Constitución de 1925, sino de otra Constitución nueva, inspirada en 1980 por los colaboradores del General Pinochet. Y esa nueva Constitución (...) no se inspiraba ya para nada en el consenso de 1945, sino que, rompiendo con él, anticipaba el venidero "consenso de Washington": consagraba prácticamente la re absolutización de la empresa capitalista, blindando constitucionalmente (...) los esquemas neoliberales (...) algo pionero en el mundo (Domènech, en López de Arnal, 2003). 
Así, nuestro "frágil <Estado de compromiso $>$ que tanto enorgullecía a la clase política y buena parte de la ciudadanía” (Grez, 2009: 17) (1932-1973), llegaba a su fin.

\subsection{Algunos antecedentes sobre la Constitución de 1980: La libertad individual en reemplazo de los derechos colectivos.}

En las próximas páginas quisiéramos entregar un breve examen de algunos de los contenidos propios del texto de la CPR de 1980 y su antecedente inmediato -la Declaración de Principios del Gobierno de Chile escrita por Jaime Guzmán en 1974- que nos parecen indicativos respecto del carácter liberal conservador de ambos textos. Es decir, que nos dan una idea clara acerca de su tono y fundamento des-colectivizador, des-universalizador y des-democratizador. Así, los principios que inspirarían la carta de 1980 ya venían expuestos en la Declaración de Principios del Gobierno de Chile publicados por la junta militar en marzo del 1974. Entre estos podemos contar: Los derechos naturales ("El hombre tiene derechos naturales y superiores al Estado"), la servicialidad del Estado ("El Estado debe estar al servicio de la persona y no al revés"), el bien común como objetivo final del nuevo diseño institucional ("El fin del Estado es el bien común general" definido como "el conjunto de condiciones sociales que permita a todos y a cada uno de los chilenos alcanzar su plena realización personal", es decir, una concepción del orden social que se apartara del "individualismo liberal y del colectivismo totalitario"), el respeto al principio de subsidiaridad ("El bien común exige respetar el principio de subsidiariedad", el que se entiende de acuerdo a la siguiente sentencia: "ninguna sociedad superior puede arrogarse el campo que respecto de su propio fin específico pueden satisfacer las entidades menores, y, en especial, la familia, como tampoco puede esta invadir lo que es propio e íntimo de cada conciencia humana"), cuestión que en última instancia supone "La aceptación del derecho de propiedad privada y de la libre iniciativa en el campo económico", y por tanto la "Descentralización funcional", es decir, la separación entre poder político y poder social (para esta visión, la libertad política es la menos importante de las libertades; la libertad económica está asociada a la libertad social; la despolitización de lo social y la tecnificación de la política).

Como vemos, el texto define una democracia autoritaria que considera a la autoridad militar como garante de la institucionalidad, una democracia autoritaria que blinda la libertad de la democracia política y que se erige sobre un pluralismo limitado que corrija los vicios democratizantes del sufragio universal (senadores designados, por ejemplo). En ese sentido, para el liberalismo católico y autoritario de la Constitución chilena de 1980, para que la persona humana sea libre, se necesita de autoridad. Es decir, si no hay mecanismos de coordinación política que son los que están llamados a producir lo común, si la política está prohibida, si sólo se promueve lo social no político, es decir la extensión hacia lo público de la persona humana (los cuerpos intermedios), sólo queda la autoridad. En ese sentido, la CPR del 80 es un texto constitucional que, tratando de excluir la democracia republicana y conjugando libertad y autoridad, representa el intento desde el corporativismo autoritario (gremialismo) por configurar un diseño institucional que asegure y blinde los elementos básicos de una "sociedad libre", distanciándose, tanto de esquemas 
que se constituyan en base a la oposición de preferencias políticas (liberalismo representativo), como en base a la oposición de clases sociales (marxismo). Dicho esto, nada mejor que una declaración del propio establishment académico chileno, para sintetizar de buena manera dichos contenidos. Citamos a Cea Egaña.

En su versión original, el articulado de las Bases de la Institucionalidad y del capítulo dedicado a los derechos, deberes y garantías fundamentales eran una proclamación, sobria y definida, de coincidencia con el constitucionalismo humanista. Efectivamente, un recuento brevísimo permite anotar valores como la dignidad de la persona y los derechos que fluyen de la persona humana; la familia como núcleo fundamental de la sociedad; la subsidiaridad del Estado; la servicialidad de este y su legitimación por contribuir al bien común; la limitación de la soberanía por el respeto al ser humano; la supremacía de la Carta Fundamental; el Estado de Derecho y la proscripción al terrorismo. En este marco axiológico se insertan los derechos esenciales asegurados en el artículo 19 (...) de la Constitución (Cea Egaña, 2005:91).

Así, ya en el Capítulo I de Bases de la Institucionalidad, en su parte dogmática, la CPR del 1980 nos señala su orientación ontológico individualista, indicando que:

Las personas nacen libres e iguales en dignidad y derechos. La familia es el núcleo fundamental de la sociedad. El Estado reconoce y ampara a los grupos intermedios a través de los cuales se organiza y estructura la sociedad y les garantiza la adecuada autonomía para cumplir sus propios fines específicos. El Estado está al servicio de la persona humana y su finalidad es promover el bien común, para lo cual debe contribuir a crear las condiciones sociales que permitan a todos y a cada uno de los integrantes de la comunidad nacional su mayor realización espiritual y material posible, con pleno respeto a los derechos y garantías que esta Constitución establece. Es deber del Estado resguardar la seguridad nacional, dar protección a la población y a la familia, propender al fortalecimiento de ésta, promover la integración armónica de todos los sectores de la Nación y asegurar el derecho de las personas a participar con igualdad de oportunidades en la vida nacional (CPR, 1980, Artículo $1^{\circ}$ ).

La soberanía reside esencialmente en la Nación. Su ejercicio se realiza por el pueblo a través del plebiscito y de elecciones periódicas y, también, por las autoridades que esta Constitución establece. Ningún sector del pueblo ni individuo alguno puede atribuirse su ejercicio. El ejercicio de la soberanía reconoce como limitación el respeto a los derechos esenciales que emanan de la naturaleza humana. Es deber de los órganos del Estado respetar y promover tales derechos, garantizados por esta Constitución... (CPR, 1980, Artículo 5).

Recordemos que el Artículo I de la CPR de 1925 en los fundamentos señalados en su parte dogmática, indicaba que "el Estado en Chile es unitario. Su gobierno es republicano y democrático representativo", que "La Soberanía reside esencialmente en la Nación", o que "La Constitución asegura a todos los ciudadanos el libre ejercicio de los 
derechos políticos, dentro del sistema democrático y republicano. Todos los chilenos pueden agruparse libremente en partidos políticos, a los que se reconoce la calidad de personas jurídicas de derecho público y cuyos objetivos son concurrir de manera democrática a determinar la política nacional"; es decir, conceptos que claramente contrastan con los conceptos vertidos en la parte dogmática de la CPR de 1980, que si bien en su Capítulo 1 también señala que "La Soberanía reside esencialmente en la Nación", complementa con declaraciones tan contundentes desde el punto de vista liberal católico como: "Las personas nacen libres e iguales en dignidad y derechos"; o "La familia es el núcleo fundamental de la sociedad". Es decir, la noción de soberanía nacional es reemplazada por el de persona humana naturalizada y su entorno familiar (sus derechos inalienables son anteriores al Estado, a la política y, por tanto, al Estado). Es decir, la esencialización ontológico - política del individuo y sus supuestos derechos naturales que sólo alcanzan nivel agregado a través de los cuerpos intermedios no politizados, sociedades o grupos sociales corporados a los que se les garantiza un grado relativo de libertad para la consecución de sus fines específicos pero alejados del mundo de la representación política.

Los grupos intermedios de la comunidad y sus dirigentes que hagan mal uso de la autonomía que la Constitución les reconoce, interviniendo indebidamente en actividades ajenas a sus fines específicos, serán sancionados en conformidad a la ley. Son incompatibles los cargos directivos superiores de las organizaciones gremiales con los cargos directivos superiores, nacionales y regionales, de los partidos políticos. La ley establecerá las sanciones que corresponda aplicar a los dirigentes gremiales que intervengan en actividades político partidistas y a los dirigentes de los partidos políticos, que interfieran en el funcionamiento de las organizaciones gremiales y demás grupos intermedios que la propia ley señale (CPR 1980, Artículo 23).

En este sentido, el Artículo 2 de la CPR de 1925 señala que: "La soberanía reside en esencialmente en la Nación, la cual delega su ejercicio en las autoridades que esta constitución establece" (no contempla limitaciones al ejercicio de la soberanía). En cambio, el Artículo 5, Inciso 2º de la CPR de 1980 señala que: "El ejercicio de la soberanía reconoce como limitación el respeto de los derechos esenciales que emanan de la naturaleza humana. Es deber de los órganos del Estado respetar y promover tales derechos, garantizados por esta constitución, así como los tratados internaciones ratificados por Chile y que se encuentren vigentes". Así, lo institucional debería constituirse teniendo en consideración el sagrado respeto a los derechos esenciales de la naturaleza humana, derechos que son anteriores y superiores al Estado y a la política.

Ahora bien, avanzando en algunos tópicos que nos parecieron relevantes, en el campo específico de la salud, por ejemplo, si la CPR de 1925 señalaba: "Es deber del Estado velar por la salud pública y el bienestar higiénico del país. Deberá cada año destinarse una cantidad de dinero suficiente para mantener un Servicio Nacional de Salubridad", el Artículo 19 de la CPR del 1980 en su numeral 9º señala: "Es deber del Estado garantizar la ejecución de las acciones de salud, sea que presten a través de instituciones públicas o privadas en la forma y condiciones que determine la ley, la que 
podrá establecer cotizaciones obligatoria. Cada persona tendrá derecho a elegir el sistema que desee acogerse, sea este estatal o privado".

Respecto del mundo del trabajo, si el Artículo 10, numeral 14 de la CPR de 1925 señalaba su protección social al referirse expresamente a "la protección del trabajo", la CPR de 1980 se centra, en este aspecto, en el concepto de la "libertad de trabajo". Es decir, el concepto "derecho del trabajo", que era parte del catálogo de los derechos sociales o de contenido económico - social, es reemplazado por el de "libertad de trabajo" (Artículo 19, numeral 16), contenido propio de los derechos clásicos de corte individual. Ejemplo de esto, es que el concepto de remuneración, que es más restrictivo (CPR 1925), fue reemplazado por el de retribución (CPR 1980), que es más amplio. Acá debemos recordar que lo que se conoce como el modelo neoliberal se asienta sobre el objetivo de control de la inflación y de equilibrio en las cuentas macroeconómicas y no en el de provisión de pleno empleo. La CPR de 1980 sintoniza con el concepto liberal de libre contratación entendiendo remuneración -de acuerdo al Código del Trabajo- como "las contraprestaciones en dinero y las adicionales en especie, avaluables (sic) en dinero que debe percibir el trabajador del empleador por causa de contrato". Así, constituyen remuneración, entre otros componentes: sueldo, sobresueldo, comisión, participación y gratificación. Ahora bien, el Artículo 19 numeral 16 permite la negociación en términos muy restrictivos, lo que no sucede con la CPR de 1925. La CPR del 80 señala que la negociación colectiva es un derecho para los trabajadores pero a su vez también señala que ese derecho puede estar prohibido en casos en que una ley no permita negociar. A su vez, señala "que no podrán declararse en huelga los funcionarios del Estado ni de las municipalidades. Tampoco podrán hacerlo personas que trabajen en corporaciones o empresas, cualquiera que sea su naturaleza, finalidad o función, que atiendan servicios de utilidad pública o cuya paralización cause grave daño a la salud, a la economía del país, al abastecimiento de la población o a la seguridad nacional".

Respecto al derecho a sindicarse, este se encuentra en la CPR de 1925 en la reforma de 1971. Aquel texto señala: "El derecho a sindicarse en el orden de sus actividades o en la respectiva o faena en conformidad a la ley. Los sindicatos y las federaciones y confederaciones sindicales, gozaran de personalidad jurídica por el sólo hecho de registrar sus estatutos y actas constitutivas en la forma y condiciones que determine la ley. Los sindicatos son libres para cumplir sus propios fines". En cambio, en el texto de Guzmán se permite el derecho a sindicarse pero su inciso final indica: "La ley contemplará los mecanismos que aseguren la autonomía de esas organizaciones. Las organizaciones sindicales no podrán intervenir en actividades político partidistas”.

Respecto de la seguridad social, la CPR de 1980 en su Artículo 19, No 18, de derecho a la seguridad social, señala en su Inciso 2o. "La acción del Estado estará dirigida a garantizar el acceso de todos los habitantes al goce de prestaciones básicas uniformes, sea que se otorguen a través de instituciones públicas o privadas. La ley podrá establecer cotizaciones obligatorias. El Estado supervigilará el adecuado ejercicio del único derecho a la seguridad social". Este artículo no tiene parangón en la CPR de 1925. Se puede decir que con dicho artículo se apoya constitucionalmente la existencia del sistema de administración de fondos de pensiones privatizados (AFP), es decir, se les da rango constitucional. 
Respecto del derecho de propiedad, la CPR de 1925 en su Artículo 10, No 10, Inciso 3, señala: "Cuando el interés de la comunidad nacional lo exija, la ley podrá reservar al Estado el dominio exclusivo de recursos naturales, bienes de producción u otros que declare de importancia preeminente para la vida económica social o cultural del país. Propenderá asimismo a la conveniente distribución de la propiedad y a la constitución de la propiedad familiar". En cambio, el Artículo 19, Numeral 21, Inciso $2^{\circ}$ de la CPR de 1980, señala expresamente que: "El Estado y sus organismos podrán desarrollar actividades empresariales o participar en ellas sólo si una ley de quórum calificado los autoriza. En tal caso, esas actividades estarán sometidas a la legislación común aplicable a los particulares, sin perjuicio de las excepciones que por motivos particulares justificados establezca la ley, la que deberá ser, asimismo de quórum calificado". Se destaca que el sentido de que la ley que regula la actividad empresarial del Estado va ligado al principio de subsidiaridad; asimismo, se crea el recurso de amparo económico, una acción que desde el punto de vista de su naturaleza jurídica, está destinado a denunciar las infracciones al mismo. El Artículo 19, Numeral 22 de la CPR de 1980, hablará en términos generales de la no discriminación arbitraria en el trato que debe dar el Estado y sus organismos en materia económica. ${ }^{18}$ Sin embargo, en su inciso $2^{\circ}$, regula justamente esa discriminación permitiendo beneficios directos o indirectos a favor de determinados sectores, actividades o zonas geográficas; o establecer gravámenes especiales que afecten a uno u otras. La evidente discriminación del inciso está marcada por la falta de móvil para otorgar tales beneficios ya que no indica que sean motivos sociales o por motivos que privilegien el interés social o nacional del país. Respecto de la no interferencia, es interesante señalar algo respecto del recurso de protección. El Artículo 20 de la CPR de 1980 señala que: "El que por causa de actos u omisiones arbitrarias o ilegales sufre privación perturbación o amenaza en el legítimo ejercicio de los derechos y garantías establecidas en los Artículo 19, Numeral 1, 2, 3 inciso (...) en lo relativo a la libertad de trabajo y al derecho a su libre elección y libre contratación, y a lo establecido en el inciso cuarto (...) podrá recurrir por si o por cualquiera a su nombre, a la Corte de Apelaciones respectiva, la que adoptará de inmediato las providencias que juzgue necesarias para establecer el imperio del derecho y asegurar la debida protección del afectado". Así, si la CPR del 25 estaba construida sobre la idea de la protección social y colectiva de los derechos de los trabajadores por medio del Estado social, la de 1980 lo está sobre la idea de la protección de los individuos en abstracto de cualquier organización que interfiera externamente en sus preferencias de orden utilitarista. El recurso de protección no existe en la CPR de 1925, y tal como lo señala Sergio Diez integrante de la comisión Ortúzar, comisión redactora de la CPR de 1980- en su texto "Reflexiones sobre la constitución del 1980":

\footnotetext{
${ }^{18}$ Todo un léxico liberal: La libertad negativa entendida para los presentes fines simplemente como no interferencia arbitraria en términos de la clasificación típica de Isaiah Berlin. Recordemos que para el liberalismo estándar, la libertad negativa separa lo privado de lo público y se funda en una idea individual de libertad, no colectiva; en cambio, para el republicanismo estándar, el orden social se basa en una idea de libertad entendida como la capacidad de una politeya para autogobernarse frente a la tiranía (Gargarella, 1999).
} 
Después de la experiencia de un gobierno marxista que decididamente quería llevar Chile al modelo socialista de la Unión Soviética, la protección de los derechos de los ciudadanos era indispensable frente a la autoridad que iba alcanzando por las vías legales, administrativas o de los resquicios, el dominio completo sobre la vida, los bienes y el destino de las personas" (...) "Era indispensable conocer el parecer de la Junta de Gobierno sobre esta materia antes de empezar a elaborar el proyecto. Existía el temor de que la Junta Militar, aunque había expresado públicamente su intención de restaurar el orden constitucional del país, no considerara oportuno en ese momento que se estableciera un recurso para dar a la justicia la posibilidad de revisar actos u omisiones de cualquiera de los miembros del poder público, entre ellos de la propia Junta de Gobierno y que fuera acusado de violar los derechos fundamentales" (...) "Era evidente que la Constitución ahora tenía dos conceptos fundamentales novedosos: el imperio del poder judicial y la creación de los recursos constitucionales, acciones que tenían la estabilidad y fuerza de la propia Constitución para proteger a las personas en el uso y goce de sus derechos fundamentales (Diez: 231, 232 y 234).

Como se puede apreciar, el recurso de protección escapa de la idea de dar protección a los derechos colectivos o sociales sino sólo en proteger en el uso y goce de derechos fundamentales a las personas consideradas en su individualidad cuasi ontológica.

Respecto del orden público económico, el Artículo 10, inciso 3 de la CPR de 1925, señala que "cuando el interés de la comunidad nacional lo exija, la Ley podrá reservar al Estado el dominio exclusivo de los recursos naturales, bienes de producción y otros, que declare de importancia preeminente para la vida social, económica, social o cultural del país". En torno a esto, Diez señala:

En septiembre de 1973 cuando la Junta Militar se hizo cargo del gobierno, la economía chilena estaba destruida y en manos del Estado. Lo anterior, unido al artículo de la Constitución de 1925 que hemos citado, hacía que la actividad de los gobernados dependiera no de su iniciativa personal o de su libertad, sino del criterio de los gobernantes. Así se puede entender por qué mi preocupación iba más allá de la defensa de la libertad y de los derechos de las personas en si misma, y que se extendiera a las normas que debían regir la economía. Yo quería establecer, con normas de orden público económico, un ordenamiento esencialmente reglado con la fuerza de una Constitución" (Se refiere al inciso tercero del Articulo 10 de la CPR de 1915) (...) "Desde el principio sostuve que en la Constitución debían establecerse principios generales. Algunos ya estaban contemplados en el artículo $1^{\circ}$, como el rol subsidiario del Estado, que era el más importante de todos. También eran derechos del orden público económico el derecho de propiedad, libertad para elegir sistemas de educación pública o privada y sistemas previsionales tantos públicos como privados. Todo esto podía quedar perfectamente consagrado en la Constitución Política del Estado y nos garantizaba una economía normal (Diez, 2013: 239).

Es así como la CPR de 1980 no se concibió sin centrarse en la regulación del orden público económico bajo la idea de la libertad individual. Al respecto, por ejemplo, el Artículo 19, numeral 21, Inciso 2ºñala: "El Estado y sus organismos podrán desarrollar 
actividades empresariales o participar en ellas sólo si una ley de quórum calificado los autoriza. En tal caso, esas actividades estarán sometidas a la legislación común aplicable a los particulares, sin perjuicio de las excepciones que por motivos justificados establezca la ley, la que deberá ser, asimismo, de quórum calificado". En ese sentido, y volviendo al comentario de Diez, podemos indicar que el Estado subsidiario se encuentra expresado en la CPR del 80 en el derecho a la propiedad, el sistema de educación público y privada, y el sistema previsional público y privado, cuestiones que él denomina cuestiones relativas al orden público económico. Estas áreas fueron introducidas en la CPR del 80, bajo el modelo de una CPR prescriptiva, esto es, que decidiera sobre el orden de la vida social y económica del país. La CPR del 80 revirtió desde sus bases la opción clásica en la materia, reconociendo a la persona supremacía sobre el Estado y trasladando todo el poder estatal no regulatorio a los cuerpos intermedios naturales creados por particulares, reservándose para si una actuación subsidiaria sólo por excepción. Así, algunos de los principios que gobiernan serían: Consagración y reafirmación protección de la persona y de su dignidad, sus derechos fundamentales y su libertad frente al Estado y a las formas de gobierno; la subsidiaridad del Estado; el principio de igualdad, no discriminación arbitraria y no afectación tributaria; el principio de propiedad privada; la intangibilidad de la esencia de los derechos y garantías constitucionales; el principio de la revisión judicial económica (recurso de protección, el que tutela casi todas las garantías de naturaleza económica primordiales, complementan el recurso de protección, requerimiento de inconstitucionalidad y el recurso de inaplicabilidad); el principio de reserva legal de la regulación económica (asignación exclusiva al legislador de la tarea de regular de la actividad económica); ${ }^{19}$ y el principio de autonomía económica (cuestión central que explica, por ejemplo, la autonomía del Banco Central, particularmente respecto de las políticas cambiarias, crediticias y monetarias; la prohibición parlamentaria de aumentar los gastos que propone el Presidente de la República; la prohibición al Banco Central de otorgar empréstitos al Estado, etc.).

Respecto del sistema previsional, la discusión sobre la naturaleza público - privada del derecho a la seguridad social fue uno de los pilares fundamentales en la discusión de la definición e instauración del Estado subsidiario como modelo económico, político y social. El comisionado más interesado en que este concepto subsidiario quedara plasmado en el Artículo 19, numeral 18 de la CPR del 80, fue el propio Guzmán:

(...) lo que interesa resolver es otro problema diferente, que es, el margen de que se puedan señalar las características de la seguridad social como sistema, el uso o no uso de la expresión "Estado" en el párrafo propiamente relativo a la seguridad social, lo que tiene importancia en cuanto a determinar si acaso ésta es una obligación exclusiva del Estado, o si es una obligación que el Estado deba asumir en forma subsidiaria, o una función que el Estado debe asumir en forma complementaria, si no se desea reconocer el carácter subsidiario. Creo que aquí están abocados al mismo tema que les preocupó con motivo del estudio de los derechos a la educación y a la

\footnotetext{
${ }^{19}$ Regular es dictar normas que permitan el libre pero ordenado ejercicio de un derecho, sin impedirlo ni prohibirlo ni hacer que su goce o disfrute resulte oneroso o difícil.
} 
salud. De ahí que le parece que tiene relevancia resolver a quien se le asigna la obligación de satisfacer de modo uniforme, solidario y suficiente los estados de necesidad, etc.; y, en caso de que esta obligación entrañe también, como lo entraña de algún modo, un cierto derecho para las personas, determinar qué posibilidad existe, o cómo se garantiza en la Constitución la posibilidad que este derecho sea ejercido a través de algún género de iniciativas de carácter privado que puedan coincidir o coexistir con la obligación estatal (Actas Oficiales de la Comisión Ortúzar, Pág. 4, Sesión 205, del 28 abril de 1976).

Así la cosas, Guzmán insiste en agregar términos explícitos del principio de subsidiaridad en el numeral sobre seguridad social, agregando:

El Señor Guzmán manifiesta que desea insistir en la necesidad de complementar, precisamente, con una definición de orden político en esta materia, la indicación que desde un punto técnico se les ha sugerido. Recuerda a la Comisión que la referencia a que alude el señor Silva Bascuñán y que hizo en el Capítulo I, relativo a las bases fundamentales de la Constitución y de la institucionalidad chilena, se limita, en cuanto a la expresión del principio de subsidiaridad, a señalar lo siguiente: "El Estado reconoce y ampara los grupos intermedios de la comunidad y les garantiza una adecuada autonomía para cumplir sus fines propios". Señala que esta es la forma muy genérica de que el principio de subsidiaridad estaría recogido en el anteproyecto de Constitución, lo que, evidentemente, no es suficiente para desprender todas las consecuencias que ese principio debe tener dentro del ordenamiento constitucional y jurídico. No pretende tampoco que se llegue tan lejos en la Constitución para tratar de que se reglamente o se aplique a casos específicos y esencialmente mutables; pero si cree que hay instituciones respecto de las cuales es necesaria una definición de conceptos en cuanto a si es una función que corresponde, ya sea privativa o preferentemente del Estado, o es una función en que el Estado actúa enmarcándose en el principio de subsidiaridad y que, por lo tanto, coexiste complementariamente con la iniciativa privada. Añade que en este aspecto le parece vital en la que concierne a una serie de instituciones, siendo una de ellas la seguridad social, y no cree que se pueda consagrar un precepto relativo a ésta última sin tomar una decisión al respecto. Estima que, por lo demás, si ya se adoptó decisión semejante en materias tales como la educación y la salud, no habrá razón para no hacerlo aquí en términos lo suficientemente generales como para que den lugar a todas las manifestaciones en la materialización específica del principio o criterio que el constituyente tiene (Actas Oficiales de la Comisión Ortúzar, Págs. 6 y 7, Sesión 205, del 28 abril de 1976).

Respecto del sistema de educación público - privado, el rol subsidiario del Estado quedó bien establecido en el Artículo 19, Numeral 11, inciso final de la CPR del 80. Había que fomentar la libertad de enseñanza y promover la idea del Estado subsidiario de orden marginal. La idea queda claramente plasmada por la opinión dada por Ortúzar en una de las sesiones de la comisión que dirigía:

Este sistema de enseñanza oficial debe estar constituido, tanto por la enseñanza propiamente estatal como particular, porque es evidente que el Estado en las actuales 
circunstancias, y quizás por mucho tiempo, no podrá eliminar la existencia de una enseñanza gratuita estatal proporcionada por liceos fiscales. Lo ideal sería la enseñanza particular, en gran parte, copara todas las necesidades educacionales de Chile, pero pensar en eso es ser muy optimista. En estos momentos, la educación particular representa apenas el $20 \%$ de la educación total y la fiscal el $80 \%$. La educación fiscal podrá decrecer para aumentar la enseñanza particular, pero en ningún momento podría desaparecer" (Actas Oficiales de la Comisión Ortúzar, Pág. 14, Sesión 136, 08 Junio de 1975).

Por último, sólo mencionar que el Artículo 10, Numeral 7 original de la CPR de 1925 mencionaba lo siguiente: "La libertad de enseñanza. La educación pública es una atención preferente del Estado. La educación primaria es obligatoria. Habrá una Superintendencia de Educación Pública, a cuyo cargo estará la inspección de la enseñanza nacional y su dirección, bajo la autoridad del Gobierno". Pero, en reformas posteriores se añadirá: "Sólo la educación privada gratuita y que no persiga fines de lucro recibirá del Estado una contribución económica que garantice su financiamiento, de acuerdo a las normas que establezca la ley. La educación que se imparta a través del sistema nacional será democrática y pluralista y no tendrá orientación partidaria oficial. Su modificación se realizará también en forma democrática, previa libre discusión en los organismos competentes de composición pluralista".

Resumiendo, y para finalizar, la CPR del 1980 asegura en su parte orgánica (Artículo 19 del Capítulo III), entre otros derechos:

$2^{\circ}$. La igualdad ante la ley. En Chile no hay persona ni grupo privilegiados.

$4^{\circ}$. El respeto y protección a la vida privada y a la honra de la persona y su familia.

$7^{\circ}$. El derecho a la libertad personal y a la seguridad individual.

$9^{\circ}$. El derecho a la protección de la salud. El Estado protege el libre e igualitario acceso a las acciones de promoción, protección y recuperación de la salud y de rehabilitación del individuo. Le corresponderá, asimismo, la coordinación y control de las acciones relacionadas con la salud. Es deber preferente del Estado garantizar la ejecución de las acciones de salud, sea que se presten a través de instituciones públicas o privadas, en la forma y condiciones que determine la ley, la que podrá establecer cotizaciones obligatorias. Cada persona tendrá el derecho a elegir el sistema de salud al que desee acogerse, sea éste estatal o privado.

$10^{\circ}$. El derecho a la educación. La educación tiene por objeto el pleno desarrollo de la persona en las distintas etapas de su vida. Los padres tienen el derecho preferente y el deber de educar a sus hijos. Corresponderá al Estado otorgar especial protección al ejercicio de este derecho.

$11^{\circ}$. La libertad de enseñanza incluye el derecho de abrir, organizar y mantener establecimientos educacionales. La libertad de enseñanza no tiene otras limitaciones que las impuestas por la moral, las buenas costumbres, el orden público y la seguridad nacional. La enseñanza reconocida oficialmente no podrá orientarse a propagar tendencia político partidista alguna. Los padres tienen el derecho de escoger el establecimiento de enseñanza para sus hijos.

$12^{\circ}$. La ley en ningún caso podrá establecer monopolio estatal sobre los medios de comunicación (...) 
$15^{\circ}$. El derecho de asociarse sin permiso previo. Nadie puede ser obligado a pertenecer a una asociación. Los partidos políticos no podrán intervenir en actividades ajenas a las que les son propias ni tener privilegio alguno o monopolio de la participación ciudadana; La Constitución Política garantiza el pluralismo político. $16^{\circ}$. La libertad de trabajo y su protección. Toda persona tiene derecho a la libre contratación y a la libre elección del trabajo con una justa retribución. La negociación colectiva con la empresa en que laboren es un derecho de los trabajadores, salvo los casos en que la ley expresamente no permita negociar. La ley establecerá las modalidades de la negociación colectiva y los procedimientos adecuados para lograr en ella una solución justa y pacífica. La ley señalará los casos en que la negociación colectiva deba someterse a arbitraje obligatorio, el que corresponderá a tribunales especiales de expertos cuya organización y atribuciones se establecerán en ella. No podrán declararse en huelga los funcionarios del Estado ni de las municipalidades.

$18^{\circ}$. El derecho a la seguridad social. Las leyes que regulen el ejercicio de este derecho serán de quórum calificado. La acción del Estado estará dirigida a garantizar el acceso de todos los habitantes al goce de prestaciones básicas uniformes, sea que se otorguen a través de instituciones públicas o privadas. La ley podrá establecer cotizaciones obligatorias.

$19^{\circ}$. El derecho de sindicarse en los casos y forma que señale la ley. La afiliación sindical será siempre voluntaria. (...) La ley contemplará los mecanismos que aseguren la autonomía de estas organizaciones. Las organizaciones sindicales no podrán intervenir en actividades político-partidistas.

$21^{\circ}$. El derecho a desarrollar cualquiera actividad económica que no sea contraria a la moral, al orden público o a la seguridad nacional, respetando las normas legales que la regulen. El Estado y sus organismos podrán desarrollar actividades empresariales o participar en ellas sólo si una ley de quórum calificado los autoriza. En tal caso, esas actividades estarán sometidas a la legislación común aplicable a los particulares, sin perjuicio de las excepciones que por motivos justificados establezca la ley, la que deberá ser, asimismo, de quórum calificado.

$23^{\circ}$. La libertad para adquirir el dominio de toda clase de bienes, excepto aquellos que la naturaleza ha hecho comunes a todos los hombres o que deban pertenecer a la Nación toda y la ley lo declare así. (...) Una ley de quórum calificado y cuando así lo exija el interés nacional puede establecer limitaciones o requisitos para la adquisición del dominio de algunos bienes.

$24^{\circ}$. El derecho de propiedad en sus diversas especies sobre toda clase de bienes corporales o incorporales. Nadie puede, en caso alguno, ser privado de su propiedad, del bien sobre que recae o de alguno de los atributos o facultades esenciales del dominio, sino en virtud de ley general o especial que autorice la expropiación por causa de utilidad pública o de interés nacional, calificada por el legislador (CPR 1980, Artículo 19).

\section{Comentarios finales}

Hemos revisado algunos antecedentes generales de diseño institucional que nos han permitido realizar un determinado acercamiento a la naturaleza de las modificaciones 
estructurales del conjunto de reglas del juego en el país desde comienzos de los ochentas. En ese sentido, hemos revisado algunas definiciones de diseño institucional desde la perspectiva racionalista, hemos entregado una versión de la evolución / involución de los derechos económicos y sociales a través de la revisión de algunos textos constitucionales emblemáticos a nivel mundial, para luego finalizar con una lectura posible de los contenidos del constitucionalismo liberal autoritario chileno de fines de Siglo XX, contenidos que conectan con los fundamentos propios de la revolución neoconservadora y des democratizadora global actual. En ese sentido, hemos tratado de circunscribir dicho texto constitucional dentro de lo que acá se ha intentado denominar: generaciones de constituciones.

Como hemos venido afirmando, en Chile, como en el resto de los países neoliberalizados a fondo (violentamente o no), el meta diseño viene reorientando, hace por lo menos 35 años, tanto la acción como los resultados de unos y otros dentro del juego social, desequilibrando la balanza obviamente hacia el capital. En ese contexto, podemos decir que los procesos de rediseño ocurridos sobre la sociedad chilena basados en la descolectivización y operados sobre lo constitucional, la propiedad estatal y el funcionamiento de la economía privada, han generado una serie de consecuencias observables en el terreno de lo político, lo económico y lo institucional (lo cultural en lenguaje estándar). En ese sentido, dichos procesos de rediseño, que serían el resultado del rompimiento unilateral del contrato social de entreguerras por parte del capital (en su versión latinoamericana: modelo nacional desarrollista o nacional popular), han traído consigo el vaciamiento político, la despolitización de la esfera económica y la social, la devaluación -en la percepción de la población- de la relevancia de la cultura de lo colectivo y lo universalista, lo que ha involucrado la caída de la actividad colectiva como forma relevante de acción social; pero además, resultados socioeconómicos de éxito relativo entre las diferentes categorías socioeconómicas, es decir, resultados de altísimos beneficios agregados para algunos sectores sociales respecto de otros, a saber, la elite oligopólico - financiera respecto de vastos sectores tercerizados, desprotejidos y precarizados de la economía nacional.

Como hemos visto, el rediseño institucional completo aplicado en el país intentó, por un lado, restituir el poder de clase de una oligarquía nacional reactualizada mediante la implantación de un patrón de acumulación neo extractivista y financiero ("el modelo chileno"); y por otro, modificar el modo en el que los agentes se desenvuelven en los sistemas de intercambio, privados y públicos para consolidar subjetivamente la revolución neoconservadora implementada (liberalismo económico y conservadurismo valórico). Creemos que mediante el diseño y puesta en ejercicio del texto constitucional del 80 (parte dogmática y orgánica) y sus códigos complementarios (civil, del trabajo, de aguas, etc.) se lograron ambos objetivos. En definitiva, un meta diseño institucional des colectivizado y des universalizado en donde la economía se ha terminado por erigir por sobre lo político (la Constitución del 80 está hecha para neutralizar la política y los cambios) ${ }^{20}$, y donde la

\footnotetext{
${ }^{20}$ De hecho, una de las más célebres frases de Guzmán fue: “(...) resulta preferible contribuir a crear una realidad que reclame de todo el que gobierne una sujeción a las exigencias propias de ésta. Es decir, que si llegan a gobernar los adversarios, se vean constreñidos a seguir una acción no tan distinta a la que uno mismo anhelaría, porque - valga la metáfora - el margen de alternativas que la cancha imponga de hecho a quienes
} 
desigualdad distributiva provocada -que al parecer se ve como un efecto buscado y esperado por parte del capital al provocar competencia, y, por tanto, incentivo a la inversión y al crecimiento- se instala como un fenómeno endémico que cada día se torna más difícil reequilibrar: ¿la desigualdad económica es producto de la desigualdad política? (En el sentido de que la presencia de poder político es el recurso necesario para generar diseños institucionales que faciliten $\mathrm{y}$ aseguren la acumulación de capital). Al parecer, la democracia, en ciertos términos, debe consistir en limitar el poder.

\section{REFERENCIAS BIBLIOGRAFICAS}

\section{LIBROS}

Fernando Atria, La constitución tramposa, Santiago de Chile, Lom, 2013.

Francisco Báez Urbina, "El problema de la acción colectiva y los movimientos de oposición ciudadana a la provisión de bienes de uso colectivo: El trazado del AVE a su paso por Barcelona, un caso relevante de estudio", Tesis Doctorado en Sociología, Universidad Autónoma de Barcelona, Barcelona, España, 2009.

Samuel Bowles, Microeconomics, behavior, institutions and evolution, Princeton, New Yersey, University Press, 2004.

Robert Castel, El ascenso de las incertidumbres, Buenos Aires, FCE, 2010.

........ Et al., Individuación, precariedad, inseguridad, Buenos Aires, Paidós, 2013.

Renato Cristi, El pensamiento político de Jaime Guzmán. Una biografía intelectual, Santiago de Chile, Lom, 2000.

Renato Cristi y Pablo Ruiz-Tagle, El constitucionalismo del miedo. Propiedad, bien común y poder constituyente, Santiago de Chile, Lom, 2014.

Sergio Diez, Reflexiones sobre la constitución de 1980. 50 años de un actor y testigo de la vida política chilena, Santiago de Chile, Aguilar, 2013.

Antoni Domènech, "Socialismo: ¿de dónde vino? ¿qué quiso? ¿qué logró? ¿qué puede seguir queriendo y logrando?”, Mario Bunge y Carlos Gambetta (eds.) ¿Tiene porvenir el socialismo?, Buenos Aires, EUDEBA, 2013, 71-124.

Jon Elster, "Reflexiones sobre marxismo, funcionalismo y teoría de los juegos", El marxismo, una perspectiva analítica, John Roemer, México, DF, FCE, 1989, 231-251

..........La explicación del comportamiento social. Más tuercas y tornillos para las ciencias sociales, Barcelona, Gedisa, 2010.

Roberto Gargarella, La sala de máquinas de la constitución. Dos siglos de constitucionalismo en América Latina (1810-2010), Buenos Aires, Katz, 2014.

.........Las teorías de la justicia después de Rawls, Barcelona, Paidós, 1999.

David Harvey, El nuevo imperialismo, Madrid, Akal, 2003.

..Breve historia del neoliberalismo, Barcelona, Akal, 2007.

Naomi Klein, La doctrina del Shock. El auge del capitalismo del desastre, Barcelona, Bolsillo Paidós, 2010.

B. Guy Peters, El nuevo institucionalismo. Teoría institucional en ciencia política. Barcelona, Gedisa, 2003.

jueguen en ella, sea lo suficientemente reducido para hacer extremadamente difícil lo contrario". Jaime Guzmán, "El camino político", en Revista Realidad, Santiago de Chile, 7 de diciembre de 1979. 
Philip Pettit, "Diseño institucional y elección racional", Robert Goodin (edit.), Teoría del diseño institucional, Barcelona, Gedisa, 2003, 75-117.

Thomas Piketty, El capital en el siglo XXI, México, DF, FCE, 2014.

Gerardo Pisarello, Un largo termidor. La ofensiva del constitucionalismo antidemocrático, Madrid, Trotta, 2011.

Richard Sennett, La cultura del nuevo capitalismo, Barcelona, Anagrama, 2006.

Thomas C. Schelling, Micromotivos y macroconductas, México, DF, FCE, 1989.

Christian Viera, Libre Iniciativa Económica y Estado Social: Análisis al estatuto de la libertad de empresa en la Constitución chilena, Santiago de Chile, Thomson Reuters, 2013.

Mario Verdugo, Emilio Pfeffer y Humberto Nogueira, Derecho constitucional. Tomo I, Santiago de Chile, Editorial Jurídica, 1994.

\section{ARTICULOS EN REVISTAS}

José Luis Cea Egaña, “Contrapunto entre el constitucionalismo de 1925 y el de 1980", Revista de Derecho, Universidad Católica del Norte, Sección Estudios, Año 12, №2, 2005, 87-92.

Renato Cristi, "La lección de Schmitt: Poder constituyente, soberanía y principio monárquico", Revista de Ciencia Política, Vol. 28, N², 2008, 17-31.

Jaime Guzmán, "En torno a la médula del mensaje presidencial", Ercilla, Santiago de Chile, 19/09/1979.

"El camino político", Revista Realidad, Santiago de Chile, 07/12/1979.

\section{FUENTES ELECTRONICAS}

Antoni Domènech, "La humanidad es una sola, no un cúmulo de culturas cerradas", Sin Permiso, 2013b [01-02-15], disponible en: http://www.sinpermiso.info/textos/index.php?id=5579

Antoni Domènech y Daniel Raventós "Después de la utopía. Entrevista”, Sin Permiso, 2010 [11-0514], disponible en: http://www.sinpermiso.info/textos/index.php?id=3685

Sergio Grez, "La ausencia de un poder constituyente democrático en la historia de chile", Revista izquierdas, [on line], 2009 [01-09-16], Año 3, No 5, disponible en:

http://repositorio.uchile.cl/bitstream/handle/2250/123041/Grez_Toso_Sergio_Ausencia_de_un_pod er.pdf?sequence $=1$

Salvador López Arnal 2003. "Entrevista político - filosófica a Antoni Domènech", 2003 [07-09-16], disponible en: http://www.nodo50.org/redrentabasica/descargas/Entrevista_TD_def.pdf

David Rosen. "Es hora de volver a llamar a la lucha de clases por su nombre", Sin Permiso, 2010 [07-05-14], disponible en: http://www.sinpermiso.info/textos/index.php?id=3679 